\title{
Rocío Quispe-Agnoli. Nobles de papel. Identidades oscilantes y genealogías borrosas en los descendientes de la realeza inca. Madrid-Frankfurt: Iberoamericana-Vervuert, 2016.
}

Todo archivo, decía Derrida, es a la vez instituyente y conservador, revolucionario y tradicional. El archivo fija, mira al pasado, conserva; pero queda ahí para ojos futuros, ofrece información, instituye nuevas, potenciales lecturas. En los estudios coloniales el archivo es nuestro mejor aliado, pero también el más peligroso. Miles de documentos aguardan a ser investigados, pero en el camino que recorremos para su estudio plasmamos nuestra propia necesidad de legitimación académica. La lectura de estos textos es a la vez liberadora y esclavizante: no hay manera de analizarlos con mirada objetiva, pero es necesario hacerlo para descubrir, renovar, releer, revisitar la historia.

Este libro de la profesora Rocío Quispe-Agnoli, Nobles de papel, analiza un material muy complejo que refleja perfectamente la disyuntiva mencionada. El estudio se centra en analizar el legajo 2346, de 804 páginas, de la Audiencia de México, que se encuentra en el Archivo General de Indias de Sevilla. Como comenta Quispe-Agnoli, este legajo ofrece 250 años de historias genealógicas y sociales de Perú y del México del siglo xvin, en la medida en que se compone de diversos documentos que cubren desde «las cédulas reales que Carlos $\mathrm{V}$ otorgó a descendientes nobles de los Incas» (22) en 1544-1546, hasta los años 1800-1801, cuando los archiveros sevillanos intentaban conseguir copias de dichas cédulas e incluirlas en el legajo.

En este sentido, la autora explica que el título del manuscrito, Cartas y expedientes sobre las pretensiones de Doña María Joaquina Inca [...] de que le reconozcan sus prerrogativas y derechos como descendientes de los reyes incas del Perú, no refleja exactamente la gran variedad de textos que contiene, ni tampoco los periodos que cubre. Resulta muy inspirador el hecho de que Quispe-Agnoli se sirva de este legajo no solo para recorrer la historia de peticiones de una familia indígena colonial, sino que, a través de ella, ofrezca una reflexión sobre esa «necesidad de autodefinirse en términos sociales, materiales, históricos y genealógicos» (23) tan propia de las comunidades coloniales y cuya disyuntiva llega hasta el día de hoy.

$Y$ es que estas familias descendientes de la realeza Inca se vieron obligadas, con la imposición del orden colonial, a demostrar su «afiliación por medios legales, que quedaban plasmados en papel, tinta y sellos oficiales» (29), entrando así de lleno en lo que Ángel Rama bautizó como ciudad escrituaria, aquel espacio producido por el desencuentro entre la minuciosidad de las leyes y la confusión 'ágrafa' de la sociedad que legislaban. Evidentemente, solo las familias nativas de alto nivel social podían desenvolverse en esta ciudad escrituaria con el fin de mantener los privilegios de que gozaban en la comunidad previa.

Partiendo de una introducción en la que expone el contexto del siglo xviII que llevó a esta familia a solicitar los privilegios que les correspondían, la profesora Quispe-Agnoli va ofreciendo diversas entradas al legajo. En los dos primeros capítulos nos acerca a las «identidades oscilantes» que se muestran en el manuscrito, construidas, al menos, desde cuatro criterios distintos pero relacionados entre sí: el lugar de origen, la posición social, el linaje familiar y la genealogía o casta propia del México del xviII. Estas identidades son oscilantes porque «cambian de posición y se acomodan según las conveniencias de los sujetos que las construyen 'desde adentro' y 'desde afuera'». Curiosamente ese "desde adentro» se caracteriza por una subjetividad híbrida: la de «ser inca - pero no ser indio- y ser español en el siglo XVIII" (47). Interesante este acercamiento que ofrece Quispe-Agnoli: cuando hablamos del 'otro' o del 'conquistado' no debemos dejar de lado el lugar que ocupaba en la sociedad prehispánica. El inca no se siente indio, por ejemplo. ¿Cómo reflejar esto en los documentos, cómo nos habla de esto el archivo?

Precisamente en los capítulos tercero y cuarto la autora analiza más en detalle las cédulas reales y los escudos de armas que aparecen en el legajo. 
No solo importa su presencia en el manuscrito, sino sobre todo el uso que los distintos personajes hacen de ellos a lo largo de la historia. Si el esfuerzo de Quispe-Agnoli por ordenar y sistematizar el acercamiento a este legajo es notable, su reflexión en los últimos capítulos es imprescindible. El libro trata de mapear la lejana relación entre ese rey «ausente e inaccesible que ordena el mundo de sus colonias en el papel» y ese mismo mundo «que se desordena en la realidad colonial de Hispanoamérica» (174). El archivo colonial no es solo un "repositorio material», sino también un concepto que condiciona nuestra visión de los «textos y temas que parecen en principio invisibles y mudos» (191): Quispe-Agnoli hace visibles y da voz a quienes han permanecido mudos en el archivo.

El volumen se completa con una serie de apéndices entre los que podemos leer varias cartas de María Joaquina Inca fechadas entre 1789 y 1793 , documentos del siglo XVII e incluso la Real Cédula de Carlos V a don Gonzalo Uchu Gualpa y don Felipe Túpac Yupanqui, fechada en 1545. Además, la autora ofrece una cronología de los eventos que contextualizan el legajo, desde 1525 hasta 1811, así como varios árboles genealógicos para situar a los descendientes de Gonzalo Uchu Guallpa, Felipe Túpac Yupanqui, Titu Atauchi y Paullu Inca.

Uno de los grandes aciertos de esta obra es rescatar la voz femenina de María Joaquina Uchu Inca, quien, durante doce años de procesos legales, se hace cargo de varios siglos de historia familiar para legitimar su ascendencia inca y acceder a los privilegios que su rango y calidad exigían. Este acceso a las «prácticas retóricas y recursos textuales» constituye el origen de lo que hoy llamamos "'expresión literaria’ creada por mujeres en América Latina» (192). Peticiones como la de María Joaquina pueden considerarse como ejemplos de producción escrita de mujeres americanas y, de la misma manera que entendemos los textos del Inca Garcilaso o de Guaman Poma, es necesario leerlos como «manifestaciones de textos autoetnográficos» en los que la mujer ocupa un lugar de enunciación propio y se inserta en la construcción del espacio colonial (192).

Desde el siglo Xvi encontramos mujeres de la élite inca como Inés Huaylas, Angelina Yupanqui y Beatriz Clara Coya que, mediante el dictado y firma de documentos como este, crean una voz con autoridad para velar por sus privilegios y los de sus familias. Así se forma, según la autora, ese «archivo de mujeres coloniales» que sigue pendiente de estudio y en el que se incluyen "representaciones acerca de formas femeninas de saber y de solucionar problemas en sus respectivas épocas» (193). Imprescindible esta lectura del archivo colonial con perspectiva de género; Rocío Quispe-Agnoli abre una senda que es necesario continuar.

Marta Ortiz Canseco Universidad Internacional de La Rioja 